\title{
New plants and plant products as food
}

\author{
By Bernard Guénault, Deere E Co, European Advertising Center, Steuben \\ Strasse 36-42, Postfach 503, D-6800 Mannheim, West Germany
}

Humans are prolific: according to statistics, we shall be seven billion people in the year 2000 and it will be necessary to feed this large population. In 1970, it was agreed that 400 million people of the world suffered from lack of food. This figure was 450 million in 1980 and could reach 500 million in 1990 . To reduce this trend, it is necessary to develop agricultural production systems which are almost indefinitely renewable.

\section{New nutritious plants}

Introducing plants into new continents has helped to diversify food sources (for example, wing bean and green amaranth in Africa), thus colonization has helped crops to travel all around the world.

Triticale. It is seldom that a new cereal appears in the field. Nevertheless, this has happened in the last 20 years with triticale, a hybrid of wheat and rye. The first example of it was created 100 years ago but it was rediscovered only in the ig6os. There are now a few hundred thousand hectares of triticale in the world. The plant associates the hardiness of rye to the nutritious qualities of wheat and its grain has a high content of lysine, cystine and methionine. It is cropped mostly for animal feeding (grain and forage), but the grey flour of triticale is used by bakers for bread, croissants and biscuits, and it is also eaten as breakfast-cereal, pancakes, waffles and doughnuts (Medina, 1978 ).

Lupin. There are several types of lupins which are cropped. The most interesting appears to be the white Lupinus albus, originating from the Mediterranean area, and Lupinus mutabilis originating from the Andes. The former is already cropped in France on around rooo ha. It has both sweet and, to a lesser extent, bitter types. The bitterness comes from the alkaloids which are not present in the sweet types. Lupin seeds contain about $50 \%$ protein and the mutabilis type contains $16-20 \%$ edible oil. There are even types which can resist a mild winter and produce a high yield.

Chick pea (Cicer arietinum). This is a major crop in many countries of Latin America, Africa and Asia. The seed contains about $25 \%$ protein and is well balanced in amino acids. This is why the flour is used in highly nutritious weaning foods such as Superamine (Algeria). High demand for the North African product and diseases in Turkish chick pea crops have considerably increased prices. Now farmers in dry areas of south-eastern France are trying to re-introduce the crop. Because of its deep roots, this plant resists drought quite well.

Wing bean. The wing bean is an important crop in south-eastern Asia where its leaves, pods and seeds, all with a very-high protein content, are much favoured. In 
Papua New Guinea there are even types of wing bean which produce valuable tubers. Wing bean is being particularly studied with the aim of improving human food in Africa and Latin America.

Evening primrose (Oenothera biennis). Oil is an important source of food energy and one of the new oil-plants studied in the UK is evening primrose of which 500 ha were cropped under contract in 1983 . According to Dr Peter Lapinskas of Efamol Ltd (personal communication), this plant offers the highest content of polyunsaturated fatty acids, especially $\gamma$-linolenic acid (GLA), which is naturally produced in the human body and helps control functions such as blood pressure and cholesterol level. Yields are poor at $\mathrm{I} \cdot 2$ tonnes/ha but they could be increased. Harvest is difficult as all seeds do not ripen at the same time.

Chinese cabbage and Fapanese chives. A Dutch plant-breeder, 'Tjerk Buishand, in Alkmaar is trying to adapt exotic vegetables to European conditions. He is especially working on Chinese cabbage, Pak-choi and Pe-tsai, which he wants to adapt to suit commercial markets. He is also cropping Japanese chives which are far thicker than European chives (Guénault, 1983).

Sweet corn. Sweet corn is also expanding in Europe; several thousand hectares are cropped in France and in Italy, partly for canning and partly for the fresh or deep-freeze markets. It is even grown in Finland using plastic mulching.

Winter purslane and tiger-nut. The high cost of fuel has justified research on glasshouse, energy-saving plants. A swiss plant-breeder, Dr Fritz Kobel in Wädenswil, recommends (personal communication) the cropping of winter purslane or miner's lettuce, a small leafed salad crop rich in vitamin $C$ which needs no additional heat. He is also working on another plant, the tiger-nut, which has edible tubers and which was cropped in many European countries but has been almost forgotten. Tubers may be imported from China where this plant is intensively bred.

Amaranth. Another rediscovered plant is amaranth, the grain of which was known to the Aztecs who used to crop thousands of hectares. This plant's seed contains $16 \%$ protein. Three main types of the plant are cropped and eaten today: Amaranthus hypochondriacus and $A$. cruentus, originating from Mexico, and $A$. caudatus from the Andes (Peru). A. hypochondriacus, with its bright red flowers, was carried to the Himalayas and became very popular in the mountains of India, Pakistan, Nepal, Tibet and China. Today, this crop is expanding in southern India (Vietmeyer, 1982). Amaranth seed is particularly rich in lysine and mixed flours of wheat and amaranth have an ideal balance in amino acids: the proteins of this mixed flour have a biological value of almost $100 v .72$ for cow's milk and 44 for maize.

Amaranth can be eaten in many ways: in India popped grains of amaranth are mixed with honey or syrup, in order to make confections, or with milk. They can be used as breakfast cereal, cooked as gruel or baked as biscuits, cakes and bread. As the grain does not contain gluten the flour must be mixed with wheat to produce bread. For a few years now, sales of the crop have been expanding in the USA, where its grain is sold in health food shops (Dull, 1983 ). 
There are also vegetable types of amaranth and their leaves are rich in proteins, vitamins and minerals. According to Grubben (1976), who researched this topic in the African Benin, three species of amaranth can be used as vegetables: $A$. cruentus, $A$. dubius, originating from Surinam, and a close relative Celosia argentea or avounvo.

Sales of some other plants, including guar, sesame and sweet sorghum, are expanding also in the USA, but on a limited scale. Dr Rothhaar in Frankenthal (Germany) has successfully used sweet sorghum for producing sugar and alcohol (Guenault, 1983 ).

Old-fashioned crops. There is also another group of unconventional food plants consisting of old plants which are almost forgotten because they are no longer fashionable or because their cropping conditions do not suit modern techniques. In addition to buckwheat (Fagopyrum spp.) and spelt (Triticum spelta) there are also: Chaerophyllum bulbosum (root chervil), Beta vulgaris (white beets), Crambe maritima (sea-kale), Tetragonia expansa (New Zealand spinach), Cynara cardunculus (cardoon), Brassica napus (swede), Pasticana sativa (parsnip), Helianthus tuberosus (Jerusalem artichoke), Stachys tuberifera (Chinese artichoke).

Peron (1983) in Angers specializes in re-introducing forgotten vegetables. With Chinese artichoke which was infested by virus, he created, through meristem cultures, virus-free types which resulted in quadrupled yields making this crop once more profitable.

\section{Extraction of proteins}

In many developing countries, people often have enough food energy, but they lack proteins, both in quantity and quality. Of course, excellent proteins may be obtained from animal products but the protein conversion rate by animals is very low. Perhaps the quality and use of plant proteins can be improved.

Grain proteins. The soya bean world harvest yields around 100 million tonnes yearly; of this $65 \%$ comes from the USA. Soya bean is partly used for human foods. One of the most surprising products is textured vegetable protein (TVP) which is 'fibrous' and can be mixed with meat. TVP production is still limited but between 1967 and 1977 it increased in the USA from 10000 to 200000 tonnes (Barometre-Porc, 1982 ). The present ( 1984 ) marketing price is $3.5^{-14} \mathrm{FF} / \mathrm{kg}$ (29p to $\oint_{0} \mathrm{I} \cdot \mathrm{I} / \mathrm{kg}$ ). In France the addition of TVP in sausages and pates is tolerated up to $30 \%$ of the total weight.

In Asia many foods are produced from fermented soya bean: miso, shoyu and hamanatto in Japan; tempeh kedelee and ketjap in Indonesia; sufu and meitauza in China etc. Fermentation improves the nutritional qualities of soya bean which, like many vegetable seeds contains anti-nutritive substances which reduce digestion: these include anti-enzyme substances (anti-trypsin, anti-amylase), haemagglutinins, goitrogens, indigestible carbohydrates, phenols, saponins and aflatoxins (Staron, 1983). 
In order to increase the protein content of human food many new foods containing plant proteins have been marketed since World War II but only a few have been successful (Orr, I972). The success of some soya-bean-protein concentrates has encouraged scientists to look for other sources of well-balanced, cheap and abundant proteins such as lucerne (Medicago sativa) or tobacco.

Lucerne proteins. Lucerne is a perennial plant with a field-life of 3 years or more. As a legume it does not require nitrogen fertilizer and can produce up to 2.5 tonnes protein/ha annually conpared with I. 5 tonnes/ha for soya bean (Guenault, I975, 1984). The group France-Luzerne is now marketing yearly 6000 tonnes 'lucerne proteins' $\left(\mathrm{PX}_{1}\right)$, a flour containing $50 \%$ protein, for livestock feeding. $\mathrm{PX}_{1}$ is a green feed because it contains a lot of chlorophyll. According to Bourdon ( 1980 ), $\mathrm{PX}_{1}$ has a high tryptophan content $(9 \mathrm{mg} / \mathrm{g}$ pellets or $18 \mathrm{mg} / \mathrm{g}$ protein), an amino acid which is often undervalued, and is rich in lysine but poor in methionine (methionine + cystine $15 \mathrm{mg} / \mathrm{g}$ ).

Lucerne juice also contains anti-nutritive substances such as phenols, flavones and saponins which are partly destroyed by heating during the preparation of $\mathrm{PX}_{1}$; they can also be eliminated by fermentation. It is also possible to discolour lucerne juice, using an alcohol treatment, to obtain white proteins suitable for human food (Staron, I 983 ). Drying lucern juice can be costly but in New Zealand the energy of the famous hot springs is used for this purpose.

Lucerne is not the only crop which can provide leaf proteins for industrial use. Protein-rich flours have been extracted from grass and successfully given to undernourished children in Jamaica and India (Staron, 1983).

Tobacco proteins. Studies on tobacco have shown that the young leaves contain very little nicotin but have been found to contain $300 \mathrm{~g}$ protein $/ \mathrm{kg}$ dry matter (DM) (Staron, 1983). The plant can produce up to 3.5 tonnes protein/ha in several cuts yearly. It grows very quickly and is cropped from the equator up to the $55^{\circ}$ parallel, in Siberia (latitude of Newcastle). According to Wildman (1979), it is possible to harvest annually 165 tonnes leaves/ha or 15 tonnes $\mathrm{DM} / \mathrm{ha}$. Using Wildman's procedure, it is possible to collect $325 \mathrm{~kg}$ crystalline fraction I protein/ ha with a superior quality to that of milk casein, $1325 \mathrm{~kg}$ fraction 2 protein/ha (quality similar to that of milk casein), as well as $135^{\circ} \mathrm{kg}$ insoluble protein/ha (protein quality similar to that of soya bean).

Protein extractions have also been tried with water hyacinth (Eichhornia crassipes), a tropical water plant which is used in China for feeding pigs and has invaded rivers and irrigation canals in Africa and America, where it is very difficult to destroy.

\section{New technologies}

New technologies applied to food include work by $T$. Staron (personal communication) featuring the extraction from wheat of a substance which is a catalyst for bread baking. Added to any kind of starch (cassava, potato, sorghum, maize), this substance also enables bread to be produced from these products. Bread is a very practical food which is quite nutritious and can be filled with other 
kinds of foods (meat, fish, vegetables). It can also be baked in large quantities by professional bakers, saving fuel in countries where wood is scarce (e.g. Sahel).

In some countries, spaghetti is much appreciated and Jacques Faure (personal communication) in Montpellier has developed a new process for producing spaghetti from maize.

In Canada, crisps are made from peas: they are quite similar to potato crisps but contain twice as much protein (Dull, 1977).

Of 80000 known plant species, between 100 and 150 are cropped and not more than two dozen are of major importance. It would be dangerous to reduce this number further as a pest or a disease could destroy a large part of a human food crop. It appears much safer to diversify edible plants and find new, nutritious, locally-adapted and hardy crops.

It is also necessary to help developing countries to produce their own food, use high-quality seeds, conserve water for irrigation, fertilize soils and improve the tilling of these soils to protect crops and harvests. They must also be guided in the efficient collection, storage and distribution of food to their inhabitants.

\section{REFERENCES}

Barometre-Porc (1982). Tourteau de Soja September, 11.

Bourdon, D., Perez, J. M., Henry, Y. \& Calmes, R. (I980). Fournees Recherche Porcine en France, 227-244.

Dull, S. (1 977). The Furrow, Corn Belt April, 2-5.

Dull, S. (1983). The Furrow, East Canada November-December, 6-9.

Grubben, G. J. H. (1976). The Cultivation of Amaranth as a Tropical Leaf Vegetable, p. 67. Amsterdam: Royal Tropical Institute.

Guenault, B. (1975). Le Sillon France July-August, Io-1 1 .

Guenault, B. (1 983). Flur und Furche September, 8-10.

Guenault, B. (1 984). Le Sillon France March-April, 7.

Medina, M. J. (1978). Triticale: does it deserve a second chance?, The Furrow, Corn Belt March, 30-31.

Orr, E. (1972). The Use of Protein-rich Foods for the Relief of Malnutrition in Developing Countries, an Analysis of Experience. London: Tropical Products Institute.

Peron, J. Y. (1983). Revue Horticole January, I 5-33.

Staron, T. (1983). L'Encylopédie Nutritionelle de l'Homme, Textes Choisis. Luce, France: INRA.

Vietmeyer, N. (1982). Ceres September-October, 43-46.

Wildman, S. G. (1979). Crops and Soils Magazine January, 7-9. 